\title{
Poverty, Social Exclusion and the MDGs: The Challenge of 'Durable Inequalities' in the Asian Context
}

\author{
Naila Kabeer
}

\section{Introduction}

'It had been thought for a fairly long time that an increase in the national product corresponded to a general rise in income. But it does not necessarily have an impact on the lowest incomes. Downward capillary action greatly depends on the initial structure of inequality. Countries with greater inequality therefore need a higher level of growth to have even a small effect on the lowest income deciles'. (Demery and Walton 2000)

'The chronically poor are not a distinct group; many different types of people experience such deprivation. People who are discriminated against, people who are stigmatised or are simply invisible to their neighbours and outside agents, those who are socially marginalised because of their ethnicity, religion, their indigenous, nomadic or caste status, migrants and bonded labourers, the tens of millions of refugees and internally displaced that live across the developing world, and also disabled people and people with severe health problems, those experiencing HIV/AIDS especially in recent years. In many situations poor women and girls and children and older people are especially likely to be trapped in poverty'. (Chronic Poverty Research Centre 2005: 3)

Economic growth has been exceptionally rapid in Asia, with many Asian countries achieving gross domestic product (GDP) growth rates of over 6 per cent annually over the last 20 years, and the overall incidence of poverty down from 32 per cent in 1990 to 22 per cent in 2000. However, the story is not one of unmitigated success. Both growth and poverty reduction have occurred unevenly across, and within, countries. As the opening quote from Demery and
Walton suggests, inequality is a major factor curtailing the impact of growth on poverty reduction and it appears to be rising in many Asian countries. Thus, Bangladesh saw income inequality rise from a Gini coefficient of 0.30 to 0.41 between 1991 and 2000; Sri Lanka saw consumption inequality rise from 0.32 to 0.40 between 1990 and 2002; while in Nepal, consumption inequality rose from 0.34 to 0.39 between 1995-6 and 2003-4. Economic growth in Vietnam and China has been exceptionally high, as has the reduction of poverty, but inequality has also grown rapidly (World Bank 2006). Estimates in India are difficult because of the non-comparability of data sets: existing studies agree that inequality has risen but differ as to by how much. Relevant data is missing for Pakistan but analysis by Easterly (2001) suggests that one reason why Pakistan has failed to translate high levels of growth into commensurate declines in poverty and human development is its high levels of economic inequality and ethnic polarisation.

My concern in this article is with those sections of the population who are least likely to have taken advantage of processes of growth in the Asian context and hence are driving the rising levels of inequality. I am interested in who they are and in the nature of the constraints that block their access to new opportunities. I argue that understanding the social dimensions of inequality, hitherto ignored in mainstream poverty analysis, provides a new lens through which to view the issue of chronic disadvantage; I illustrate this proposition by examining its relevance to achievements reflecting the Millennium Development Goal (MDG) concerns with poverty, health and education. I conclude by drawing out some broad lessons for national and international policy makers. 


\section{Social exclusion and the challenge of 'durable inequality'}

Many dimensions of disadvantage can be captured by conventional headcount approaches to poverty that focus on economic constraints, drawing attention to the shortfalls in income and assets which give rise to shortfalls in the satisfaction of basic needs. Such approaches take the individual, or the individual household, as their unit of analysis and lend themselves to what has been described as a 'vertical' model of inequality (Stewart 2002). These rank individuals or households by their position in the income or asset distribution in order to assess the extent of economic inequality in a society: Gini coefficients and the ranking of households by income/asset/expenditure quintiles or deciles are measures of vertical inequality.

However, investigations into the persistence of poverty, even in situations of economic growth, have highlighted the significance of forms of disadvantage that are not fully captured by economic measures and approaches (Kabeer 2000, 2005a). These revolve around social identity and reflect the cultural devaluation of people based on who they are (or rather who they are perceived to be). The identities in question may relate to groups of people who acknowledge their common membership, have shared beliefs and values and act in collective ways. Caste, ethnicity ${ }^{1}$ and religion are examples of such group identities. Alternatively, the identities may relate to categories of people defined on the basis of some shared characteristic rather than shared values and way of life.

The durable nature of this form of disadvantage means that people bearing devalued identities are likely to be disproportionately represented among the poor, as well as among the chronic poor - as the opening quote from the Chronic Poverty Research Centre (2005) report suggests. As the quote also suggests, gender constitutes a specific form of categorical disadvantage in conditions of poverty. The intersection of gender-based discrimination and economic deprivation means that women from poor households represent a particular category of social exclusion, facing greater discrimination in meeting their basic needs than men from poor households and more likely to slide into greater poverty in situations of crisis.

There is often a spatial dimension to poverty that goes beyond the rural-urban disparities documented.
Spatial disadvantage within rural areas tends to be associated with remoteness, low agricultural or resource potential, weak integration into the national economy and poor services. Locationspecific characteristics can lead to a concentration of environmental, economic and social disadvantage in territorially excluded neighbourhoods. These tend to be characterised by 'subcultures' of violence, criminality, drug dependence and squalor (Beall 2002).

\section{The implications for income poverty}

Dalit ('untouchable' castes), adivasis (tribal groups) and religious minorities represent socially marginalised groups in the Indian context. ${ }^{2}$ Estimates from the 2000 National Sample Survey suggest that dalits constituted 20 per cent of the rural population, but 38 per cent of the poor, while adivasis made up 11 per cent of the rural population but 48 per cent of the poor. In urban areas, figures were 14 per cent and 37 per cent, respectively for dalits and 3 per cent and 35 per cent for adivasis. In addition, estimates using the same data set suggest that poverty was around 30 per cent for minorities (mainly Muslim) but 16 per cent for non-deprived groups. There has been some decline in poverty among dalits between 1993-4 and 2000, lower than for the rest of the poor, but very little among adivasi groups. This partly reflects the fact that, unlike dalits who are dispersed across India, adivasis tend to be geographically concentrated in certain states.

A more accurate picture can be provided by focusing on states with higher-than-average concentrations of adivasis. For instance, 24 per cent of the population of Orissa is adivasi compared with 9 per cent of the national population. Most of these tribal groups are to be found in remote, forested rural areas in the poorer southern districts rather than in the more prosperous coastal districts. Poverty in Orissa was 47 per cent compared with a national level of 26 per cent. However, it was 87 per cent in the rural southern districts and 92 per cent among adivasi groups in these districts. While being located in the more prosperous coastal areas did have the effect of reducing poverty among adivasis to 67 per cent, it was still higher than the 32 per cent incidence of poverty for the coastal districts as a whole (de Haan and Dubey 2004).

The greater poverty of socially excluded groups cannot simply be explained by their lower levels of 
assets and education. Using national data, Dubey (2004) found that, holding a variety of individual and household characteristics constant (such as education, occupation, age and gender of household head), dalits were still 19 per cent more likely to be poor than the rest of the population, while adivasis were 10 per cent more likely to be poor. 'Other backward castes' were 5 per cent and Muslims 3 per cent more likely to be poor. Muslims tend to be at a greater disadvantage in urban areas where as many as 40 per cent of Muslims, compared with 22 per cent of Hindus, are found in the bottom 20 per cent of the income distribution. Using 1993/4 data from Uttar Pradesh, Kozel and Parker (2003) found that half of the difference in per capita consumption between dalit and adivasi households and the rest of the population could be explained by differences in assets, while half was due to differences in returns to those assets. Dalit and adivasi households also suffered from lower returns to education. Lanjouw and Zaidi (2002) report a similar pattern in Andhra Pradesh.

In Nepal, dalits are at the bottom of the social ladder and report the lowest human development indicators, but poverty also tends to be higher among the janjati (indigenous) groups than the rest of the population, with women in these groups at a particular disadvantage (Gardener and Subrahmanian 2005; Tomei 2005). In Bangladesh, poverty is highest in areas in which tribals are concentrated, mainly in the Chittagong Hill Tracts. In Pakistan, religion, language (a proxy for ethnicity) and caste/kinship status were found to be correlated with different measures of disadvantage. Using national level data, Carraro (2004) found that the incidence of poverty was 39.6 per cent for religious minorities who made up around 4 per cent of the total population, and 24.6 per cent for the rest. Poverty levels were also higher among landless occupational groups.

Data from the Philippines suggest that indigenous and tribal groups benefited less than the rest of the population from declines in poverty. The incidence of poverty in the country declined from 34.3 per cent in 1991 to 27.5 per cent in 2000. However, the incidence of poverty in Mindanao, which has a high proportion of indigenous people, ranged between 63 and 92 per cent, compared with less than 6 per cent in Metro Manila (Tomei 2005).

In Vietnam, national level estimates confirm that, despite rapid declines in poverty in recent years for all groups, the ethnic minorities continue to constitute a distinctly poorer group within the population. Data from successive Living Standards Measurement Study (LSMS) (1998, 1999 and 2002) show declines in poverty among the Khinh/Chinese majority from 54 per cent to 31 per cent to 23 per cent, respectively. Among the ethnic minorities, it declined from 86 per cent to 75 per cent to 69 per cent, respectively (cited in Swinkels and Turk 2004).

Ethnic minorities made up 9 per cent of the People's Republic of China in the mid-1990s, or over 100 million people (Gustafsson and Shi 2003). They used national samples of rural China from 1989 and 1995 to compare changes in their economic situation. Ethnic minority households reported 19 per cent of the per capita income of the ethnic Han majority. Between the two survey years, the average income grew by 52 per cent for the majority households but only 22 per cent for the minorities.

Female headship does not always correlate with greater poverty, but there is a far more consistent relationship between certain kinds of female heads (those who are widowed, deserted or divorced) and poverty. Building on evidence primarily from Asia, Sender (2003) concluded that the poorest rural households (the bottom 15-20 per cent of the income distribution) are characterised by 'stylised facts': a high ratio of adult females to males in household composition; primary reliance on female earnings because the women are divorced, deserted or widowed or because the adult male is incapacitated in some way; low levels of education among adults: high rates of fertility and infant and child mortality; and a lack of basic assets.

Data from Bangladesh fits these stylised facts. A study by the Bangladesh Rural Advancement Committee (BRAC 2004) reported that 40 per cent of households among the rural ultra poor were headed by women compared with a rural average of 9 per cent; 54 per cent did not own their homestead land compared with 6 per cent of the rural population; under-five mortality was 14 per 1,000 live births compared with a rural average of 11 per cent; total fertility rate was 5.45 compared with a rural average of 3.54, and adult literacy rates were 7 per cent compared with a rural average of 38 per cent. Analysis of panel data by Kabeer (2004) found that female-headed households were indeed poorer than the rest and likely to remain poor over time. 
In Indonesia, a study by Sender and Pincus (2001) used the criteria of 'households where no adult over the age of 20 had any education' to identify most vulnerable households. These were found to have few assets and consumer durables, and to experience shortfalls in basic needs (57 per cent said they did not have enough food to meet their needs compared with 41 per cent of other households). In addition, 55 per cent of the rural vulnerable had no adult working males compared with 41 per cent of the rest of the population, while 50 per cent had no adult males compared with 32 per cent of the rest.

Gangopadhyay and Wadhwa (2003) show that the general category of female-headed households are poorer than male-headed households in urban areas of India, but in rural areas it was households headed by widowed or divorced women that constituted the poorest group. Participatory Poverty Assessments in Pakistan (Government of Pakistan 2003) report that female household heads and widows, particularly those with young dependants, were systematically identified as among the very poor in all the provinces. In Vietnam, female heads do not emerge in studies as a particularly disadvantaged group but households entirely reliant on female earnings were found to be poorer than the rest and had lower levels of adult education, small landholdings and fewer assets (Kabeer and Van Anh 2001).

\section{The implications for health and education}

Higher levels of poverty among socially excluded groups translate into poorer levels of human development in terms of both health and education. In India, percentages of children (aged three years or under) who were underweight for their age was between 54-56 per cent among dalit and adivasi groups, compared with 44 per cent for the rest of the population. Infant mortality rates were 83,84 and 68 per 1,000 live births, respectively for dalit, adivasi and other groups, while under-five child mortality was 119, 126 and 92 per 1,000 live births. Maternal mortality rates are highest in tribal areas, where 65 per cent of women are anaemic compared with 48 per cent for the general population.

Analysis of National Family Health Service (NFHS) data (1998-9) in India shows that while the proportion of school-going children from dalit communities increased significantly in the 1990s, non-attendance continued to be higher than the rest of the population: 20 per cent in the $6-10$ age group compared with 16 per cent more generally, and 29 in the 11-14 age group compared with 23 per cent more generally (Nambissan 1996; 2000). Moreover, only 43 per cent of dalit children completed primary schooling compared with 58 per cent of other castes, while 42 per cent completed middle schooling compared with 63 per cent of other caste children in the relevant age groups. In their analysis of rural household data from Bihar, Himachal Pradesh, Madhya Pradesh, Rajasthan and Uttar Pradesh, Dreze and Kingdon (2001) found that children from dalit and tribal groups were much less likely to go to school, even when household wealth, quality of schooling, parents' education and motivations were taken into account.

In Nepal, estimates by Lucas (2004) suggest that infant mortality rates among dalit groups were 1.4 times that of the rest of the population, amounting to an additional 32 deaths per 1,000 births. Regarding education, children from dalit groups in relevant age groups were 1.6 times ( 1.7 for males and 1.5 for females) as likely not to be attending primary school than the rest of the population, with an attendance rate of 14 percentage points (12 for males, 17 for females) below that of the nonexcluded. Those in the 15-24 age group were 1.5 times (1.8 for males and 1.3 for females) more likely to have no schooling, a gap of 8 percentage points (11 for males and 5 for females).

The 2002 Vietnam National Health Survey (cited in Vietnam Consultative Group 2003) shows an overall improvement in children's nourishment in recent years, but at a slower pace among ethnic minorities. While 23 per cent of children from the majority Khinh/Chinese groups were underweight, the figure for children from ethnic minorities in the northern mountains was 34 per cent, and 45 per cent for those in the central highlands. The degree of malnutrition among minority children was also more severe: one-quarter of underweight ethnic minority children suffered 2-3 level malnutrition, compared with one-tenth of underweight children overall. Gender differentials favoured boys. Estimates by Lucas (2004) suggest that the infant mortality rate among ethnic minorities was 1.7 times higher than the rest of the population, an additional 14 deaths per 1,000 births.

With regard to education, the data from the Vietnam report show that while overall primary 
school enrolment rates are high (91 per cent), they are below 70 per cent for five ethnic minorities in the Central Highlands (the Ba-na, the Gia-rai and the Xo-dang) and in the Northern Uplands (the Dao and the Hmong). There is also a clear ethnic divide between the Khinh (65 per cent) and other groups (52 per cent) in both net and gross lower secondary school rates, while for four of the five ethnic minorities, net enrolment rates are below 20 per cent. Girls' education lags behind that of boys at primary school level for the three ethnic groups in the Northern Uplands (Tomei 2005).

China has experienced a steady improvement in infant mortality rates, but both infant and child mortality remain high among ethnic minorities; estimates from one province in the mid-1990s suggested overall provincial rates close to 80 per 1,000 but rates as high as 167 per 1,000 for specific ethnic minorities, including the Miao, compared with rates of 15-25 per 1,000 in predominantly Han provinces. A study by Foggin et al. (2001) explored the determinants of risk of child mortality among the Miao in Yunnan province in China. They found that households which reported greater geographical mobility of members, greater utilisation of healthcare provision and higher family income all reported lower levels of child mortality, while those with a history of tuberculosis and weak social networks had higher levels.

\section{Social exclusion as process}

The clustering of disadvantages of various kinds illustrated by these figures helps to explain the persistence of poverty among the socially excluded over the lifetime of individuals, and sometimes over generations. In this section, I touch on some of the mechanisms that drive processes of social exclusion.

\subsection{Cultural devaluation of groups and categories and the internalisation of inferiority}

Processes of cultural devaluation are key mechanisms through which the social exclusion of certain groups and categories by other dominant groups is perpetuated as a property of societal structures.

One experiment in India found that dalit schoolchildren performed as well as children from other caste groups in solving mazes in exchange for payment, when their identity was concealed from their fellow students, but that they scored less well on average than the rest when their identity was made public (Hoff and Pandey 2004). The negative expectations of others can undermine the capacity to perform by those so viewed.

\subsection{The economic dynamics of social exclusion}

The economic dynamics of poverty among excluded groups are mediated by processes of cultural devaluation. For instance, while gross inequalities in land distribution are recognised to act as a constraint on growth (World Bank 2000/2001), excluded groups often do poorly in land distribution not only because they cannot afford to buy or claim land but also because they are not permitted to do so on caste grounds.

Social exclusion may also be associated with the cultural assignment of excluded groups to the worst paid and most demeaning jobs in the occupational hierarchy. Studies suggest that social exclusion also incorporates financial exclusion: better-off households monopolise available credit from professional moneylenders but pay lower rates of interest. This asymmetrical distribution of land, credit and assets gives rise to interlocking markets, whereby poorer households borrow from, work for, share crop land and sell harvests to a single landlord/moneylender. The lack of access to institutional financial services, and consequent reliance on usurious forms of credit, is an important factor behind bonded labour.

However, while interlocking markets trap the poor in highly clientilist, sometimes coercive, relationships, they also offer some degree of protection in the face of insecurity. Larsen (2003) notes how the outlawing of the kamaiya bonded labour in Nepal, without proper follow-up in terms of providing alternative forms of employment, was met with protest on the part of freed kamaiya labourers:

'While the kamaiya system grossly exploited Tharu labourers for generations, it in many cases also secured the family basic necessities throughout the year. The immediate result of the ban of the kamaiya system in July 2000 was indeed the sudden presence of freed kamaiyas who no longer had any means of obtaining these basic necessities'. (Larsen 2003: 41)

\subsection{The intergenerational transmission of poverty} The hereditary association between socially excluded status and ascribed occupation is one way in which 
poverty is transmitted across generations. However, limitations on the prospects for occupational mobility reinforce this process by circumscribing parental aspirations for children. Consequently, children from marginalised groups tend to reproduce parental patterns of illiteracy and early entry into work. Using all-India data on rural households, Borooah and lyer (2005) found that along with household income, the presence of a school and other government services in the village, literacy of parents and parents' occupation played a significant role in explaining school enrolment, and likelihood of continuing in school once enrolled. In addition, boys were more likely to be enrolled and continue at school than girls while children from dalit, tribal and Muslim households were less likely to be enrolled than children from other households. Ascribed occupational identity also ensures that children inherit the restricted life options of their parents. As a report on begging in Pakistan points out, its castebased nature among both marginalised Muslims and Hindus 'means that for children, their line of work is pre-determined to a large extent and their options are limited. This is especially dangerous for girls, who will find themselves - often but not always - used as sex workers by their families to supplement their income' (CSR 2004: 21).

\subsection{The dynamics of exclusion in social provision: availability and quality}

The economic vulnerability of excluded groups is reinforced by the biased provision of basic services which could improve their well-being, productivity and hence their livelihood prospects. Betancourt and Gleason (2000) used Indian district-level data to explore the determinants of health and educational provision by the state, using the number of stateprovided doctors, nurses and teachers per ten persons in rural areas of the district as their measure of provision. They found that the most important source of variation at the district level related to religion and caste: the higher the percentage of rural scheduled caste and Muslims in the district population, the lower the provision of medical and educational services. Bharat et al. (2003) provide qualitative evidence on the terms of provision and health outcomes in the Indian context. They note that along with lack of respect for poorer patients, particularly women, public health service providers hold strong stereotypes of population groups which fuel the blaming of specific social groups for nonachievement of contraceptive targets.
In Vietnam, there has been an overall improvement in attendance by health workers at birth deliveries, but attendance is lower, and might even be dropping, in the mountainous areas. Trained health workers attended about 72 per cent of deliveries at the national level but only 60 per cent in the coastal and highland areas (Duong et al. 2004). Compared with a national figure of 17 per cent in 2002, 33 per cent of women in the north-east, 65 per cent in the north-west and 40 per cent in the central highlands gave birth with no assistance from qualified health workers. Disaggregating further, 75 per cent of ethnic minority women in the central coast and central highlands fell into this category. Duong et al. (2004) note that financial costs play a role in explaining exclusion, as do various aspects of the quality of provision that were very biased against poor and marginalised groups. Gender in particular was relevant. Reluctance to seek help from male health workers and the difficulties of recruiting women to work in remote mountainous areas, together with distances involved, are major factors.

\section{Political marginalisation}

Lack of voice is a key dimension of poverty more generally, but of social exclusion in particular.

In Nepal, Brahmins and Chetris maintained around 60 per cent presence in the legislature, while dalits were almost entirely absent right through from 1959 to 1999. Women too were barely represented in parliament throughout this period. Civil service positions are also disproportionately drawn from Brahmin/Chetri groups (83 per cent). ${ }^{3}$

Since excluded groups are often a minority with little power, there is no incentive for political parties to take their interests into account. They may be excluded from competing electorally by the eligibility criteria that embody cultural or ethnic biases. In Cambodia, for instance, the requirement that candidates for commune council elections must read and write in Khmer automatically excludes a large proportion of its tribal and indigenous population (Tomei 2005).

The non-recognition, and hence non-involvement, of the representative institutions of indigenous groups in development processes serves to further disenfranchise them. Non-recognition of customary land tenure arrangements or usufruct or ownership rights for forest dwellers and upland people is one of 
the main causes of their pauperisation and political, social and economic exclusion (Tomei 2005). Forest departments have traditionally held police and judicial powers, in addition to administrative powers, to enforce tightening state control over forest lands, resulting in forest dwellers being treated as criminals or squatters on their own land. In some countries (e.g. Thailand) forest dwellers are not recognised as citizens (Vandergeest 2001).

Exclusion also breeds resistance. While indigenous peoples in the Bangladesh Hill Tracts did not share a sense of 'unity' historically, they now refer to themselves as 'the jumma nation' (jumma is the term used by mainstream Bengali society to refer to their shifting cultivation practices) to express a political response to the adversities, deprivations and exclusions that they have experienced under successive regimes (Tomei 2005). Insurgency by indigenous communities in the face of exclusion has often been met, as in the case of the Chittagong Hill Tracts, with military force. In Pakistan, the Poverty Reduction Strategy Paper (PRSP) has noted that 'persistent poverty and inequalities provide a fertile breeding ground for ethnicity, sectarianism and lawlessness'. However, ethnicity and religious sect are not identified as a factor in generating poverty and inequality.

Beall (2006) notes that conditions of rapid urbanisation in Southern countries in the context of unregulated globalised industrialisation and climate change have rendered low-income households in urban areas vulnerable to specifically urban, new, forms of vulnerability. As urban populations grow and become more differentiated, social distance between groups can become magnified. Varshney (2001), for instance, found that only 3.6 per cent of deaths related to communal violence between 1950 and 1995 occurred in rural India. Moreover, eight cities representing 18 per cent of India's urban population (and 5 per cent of its total) accounted for as much as 46 per cent of deaths from communal violence.

\section{Some policy implications}

It is clear from the evidence provided that mainstream models of growth, service delivery and democracy have done little to address the intransigent forms of disadvantage associated with social exclusion. In examining practical efforts to address the problem, some key principles emerge as the basis for the design of future policies.
Universalist approaches are essential to building a sense of social solidarity and citizenship, particularly critical for excluded groups. Universal coverage also gives privileged groups more of a stake in policy outcomes, a greater willingness to contribute to them and hence the possibility of cross-subsidising marginalised groups. At the same time, the fact that it is their 'difference' from the rest of the poor that has led such groups to be left behind or locked out of processes of growth and development suggests that 'universality' should not be taken to imply 'uniformity'. There are strong grounds for plurality and diversity within universal frameworks of provision.

Existing targeted programmes have served as a means of compensating for government weakness in delivering on universal services rather than as a means of addressing exclusion. The achievement of 'inclusion by design' will need careful thought, with attention to building in incentives to promote such outcomes (Gardener and Subrahmanian 2005). Targeted programmes may be as marginalising as poorly implemented universal approaches if they rely on 'labelling' practices that reinforce stigma (Beall 1997). In the final analysis, the greater the participation of excluded groups in the design of programmes and in the political decision-making processes which impinge on their lives, the less necessary it may be to address their problems in isolation from the rest of the population.

Also emerging is the inadequacy of policies which target individuals in tackling problems which are essentially collective and group-based. In fact, individual solutions may leave marginalised groups more isolated and impoverished than before. The need for more collective approaches introduces another route through which 'difference' may have to be built into the design of policies.

Another principle is the need to go beyond 'ameliorative' approaches that address the symptoms of the problem to 'transformative' approaches that address its causes. It is quite possible to meet the basic needs of the chronic poor without strengthening their capacity to meet their own basic needs, thereby leaving their longer-term vulnerability intact. Addressing the causes of social exclusion means breaking the processes by which disadvantage is reproduced over time and across generations. There is scope here to explore multi-pronged approaches that address different dimensions of disadvantage. 
Finally, there is a clear need for collaboration by different institutional actors. While markets by their very nature tend to exclude those who are economically vulnerable, the state is unlikely to be able to address the problems of the excluded on its own. Instead, examples of good practice in this field generally draw together actors from different spheres of society: corporations, non-governmental organisations (NGOs), governments and donors. They also include the organisations of the excluded themselves who are in the best position to articulate the nature of the problem and to point in the direction of solutions. Bearing these in mind, I now look at examples of attempts to tackle the different dimensions of social exclusion to draw out some broad policy lessons.

\subsection{Addressing social exclusion: the role of information}

Information has an important role to play at a number of different levels. As Estivill (2003) points out:

\section{'Tackling social exclusion is dependent on the commitment of government but also the attitudes of society as a whole towards those it excludes. Very often, the first response is denial and concealment. The precondition for formulating strategies is to "bring it to the surface, make it visible and give it recognition".' (Estivill 2003: 94)}

Research, studies and statistical documentation can help to inform policy design as well as influence public discourse. The media play an increasingly powerful role in shaping everyday perceptions about difference and diversity within a society and can be mobilised to educate, inform and entertain in ways which break down some of the barriers that separate socially excluded groups from the rest of society.

However, getting information to excluded groups is as important as educating the general public about social exclusion. In an analysis of why indigenous groups in Nepal did not utilise government health services (Bhatia et al. 2004 cited in Gardener and Subrahmanian 2005), lack of information was stressed as a major factor on the demand side: lack of awareness of what was available as well as of the benefits, costs and risks associated with different forms of health provision.
Knowledge about rights, entitlements and the rules that govern provision can build the awareness of excluded groups and strengthen their demand. It can also result in desirable policy outcomes: the Thai media campaign is credited with reducing the incidence of HIV/AIDS to a point where the country can now consider a fiscally viable programme for treating it (World Bank 2006).

\subsection{Equalising economic opportunities}

\section{Access to land}

There is a strong case for public policy to promote the accumulation of assets by poor and excluded people in order that they are able to benefit from processes of growth and to contribute to them. Policies on this front may take the form of land reform. Even where there may not be enough land to benefit all sections of the poor, land reform can have the effect of damping down the monopoly bargaining power of large landlords. However, land reform is likely to be a long-term and challenging process. Other legislation, such as revision of land legislation to secure longer-term tenancy arrangements, resolution of disputes regarding interpretation and enforcement of land rental arrangements are possibilities. Where tenant protection has been seriously implemented, as in West Bengal, it has led to a rise in productivity (World Bank 2006).

The ILO INDISCO ${ }^{4}$ experience in the Philippines is cited as an example where the potential and capacity of indigenous communities to respond and solve collective problems was strengthened. The principle here was the integrated 'ancestral domain initiative', where collective rights over ancestral land and resources are recognised by government agencies, often accompanied by strengthening of traditional decision-making bodies and organisations. Successful indigenous-driven development processes involve the integration of ancestral domain management into initiatives for empowerment through education, capacity building and skills training. It is important however to promote the inclusion of women in such initiatives since gender inequalities may be a feature of some indigenous cultures.

\section{Infrastructure}

The physical isolation of marginalised groups makes the provision of infrastructure a priority if they are to benefit from the spread of markets and services. Roads can help promote markets and migration and 
undermine traditional structures of oppression by opening up closed societies to new opportunities.

\section{Financial and agricultural extension services}

Credit has proved to be an important resource for those in self-employment, but along with other sections of the poor, socially excluded groups have either found it difficult to access finance or only been able to access such finance on usurious terms Microfinance initiatives have involved governments and NGOs. The kind of approach adopted makes a difference to outreach outcomes reported. For instance, a recent study of 20 microfinance institutions (MFls) in India (EDA Rural Systems 2004) found that the group-based lending approach was considerably more successful than individual lending programmes in reaching the poor: 43 per cent, compared with just 15 per cent. They were also better at reaching the socially excluded: 35 per cent of the membership of group-based MFls came from scheduled caste and scheduled tribe households compared with just 32 per cent of individual lending organisations. Group-based approaches were also more likely to target women: 95 per cent compared with just 35 per cent of individual clients. There was very little difference in these outcomes by different types of group approaches. However, group approach did make a difference to reaching the very poor. MFls using the self-help group model performed better than those using the Grameen group model: 11 per cent of their membership were drawn from the very poor compared with 8 per cent of Grameen group members and just 3 per cent of individual clients (EDA Rural Systems 2004).

\section{Health and education}

Labour remains the most abundant asset of poor and socially excluded groups and investments in human capabilities contribute to both their well-being and their productivity. One of the challenges governments face is how to entice qualified professionals into rural areas.

Gonoshasthya Kendra, an NGO in Bangladesh, adopted the barefoot doctor model from China to train female paramedics to provide healthcare outreach to the poor. It has also been operating a health insurance scheme with a sliding scale of premiums that allows some degree of crosssubsidisation of its services to the very poor. Thailand has used financial incentives in the area of health. In Indonesia, doctors had to complete compulsory service in health centres for five years, with shorter periods for more remote areas, before they could obtain a lucrative civil service post. This increased the number of doctors in health centres by an average of 97 per cent from 1985 to 1994, with gains of more than 200 per cent for most remote rural areas. Roving extension clinics have been used to visit sparsely populated areas in Afghanistan to provide care locally or help with transportation to better facilities when required.

Both Malaysia and Sri Lanka have achieved improvements in maternal mortality rates by making competent professional midwives and supervisory nurse-midwives widely available in rural areas to assist in deliveries at home or in small rural hospitals. Transportation or transportation subsidies are used to enable emergency visits to hospital in Bangladesh. India and Pakistan have trained community health workers to scale-up service delivery for a wide range of services (malaria prevention, immunisation and family planning). Through a village health worker programme that monitors infant health and weight for the first month, rural infant mortality in India was cut by 50 per cent between 1995 and 1998.

Education has been singled out as an important route to eliminating child labour and thus tackling the intergenerational transmission of poverty. The Bangladesh government introduced its food-foreducation programme in the early 1990s, which along with the scholarship for girls, has helped to increase enrolment rates, close the gender gap in education and increase the age of marriage for girls (IFPRI 2005; Amin and Arends-Kuenning 2000). In India, special programmes in education include midday meals, free uniforms, free tuition fees (all universal), and formula funding to allocate more resources in areas where girls' education is a challenge.

Directing universal programmes to habitations underserved by service providers can be combined with a strong element of demand mobilisation to determine the shape and form of services. The experience of Save the Children in Nepal, for instance, has been that it is more effective to 'broker' inclusive practices within an 'education for all' approach than to target special provisions to marginalised children (Gardener and Subrahmanian 2005). The Educational Guarantee Scheme in Madhya Pradesh guarantees state provision of a 
primary schooling facility to children in a habitation where there is no such facility within $1 \mathrm{~km}$ within 90 days of receiving a demand for it from the community, with at least 25 learners in the age group 6-14 from tribal areas and 40 in non-tribal areas. Evaluations suggest that tribal areas have benefited disproportionately from this provision and that there has been a sharp reduction in the numbers of out-of-school children.

In Orissa, ActionAid has been working with the local government and a number of NGOs to address the educational needs of children from families who were forced to migrate to pay off their debts. Residential care centres have been set up in primary schools with the support of the community to house children whose parents were migrating for a period of six months. Schools are also offered at the destination site. Most of the migrants were tracked to destinations in Andhra Pradesh where ActionAid has launched Bridge Course Centres for children who had migrated with their parents. The intervention thus offers parents the possibility of educating their children either at the source or the destination of migration (Gardener and Subrahmanian 2005). A review of microfinance organisations across the world identifies some of the features that are likely to enhance utilisation of social services and thus contribute to the MDGs (Kabeer 2005b)

Along with promoting access to education, there are issues of quality and relevance. Classical educational models assume the existence of a mono-lingual and mono-cultural student based on the idea of homogeneity of beliefs, culture and language. However, there is now increasing recognition of the need for bilingual education. Instruction is initially provided in the mother tongue of different groups, with gradual progression to the mainstream language.

Recruiting service providers from marginalised communities is an important means of signalling state commitment, bridging the social distance between mainstream services and excluded groups and providing a powerful role model for the community. It is also likely to help build parental and community support and involvement. In Mongolia, a recent attempt to establish pre-school units has been successful in using the traditional gers as training centres during the summer. Teachers are nomads as well, moving with their families and stock together with a group of households involved in pre-school education programmes. In India, the Rural Litigation and Entitlement Kendra (RLEK), together with the Van Gujjars (indigenous forest nomads) in Uttaranchal, have devised an innovative approach whereby local teachers migrate with the community and implement a culturally adapted curriculum.

\subsection{Social protection for marginalised groups}

The importance of social protection to deal with the vulnerability of the poor has assumed increased importance in the development agenda in response to a greater appreciation of the different risks and uncertainties that keep poor people trapped in poverty. Social protection policies consist of the various ways in which policy makers support the social protection efforts of poorer sections of society. Policies may relate to the macro-level to ensure that uncertainties associated with growth are factored into policy design, or they may consist in an integrated array of instruments and interventions intended to prevent, mitigate or cope with risk (Farrington 2005).

The new thinking on social protection emphasises its redistributive potential and its synergy with development objectives as well as its relevance to rights-based approaches to poverty reduction (Farrington 2005; Conway and Norton 2002; Devereux and Sabates-Wheeler 2004). Redistributive potential rests on the careful design of social transfer programmes to guard against leakage and high administration costs. The increasing possibility of automated pay points, and the use of post office and bank accounts rather than local officials, are promising (Farrington et al. 2003). Groups need to know who is eligible and what the rules of provision are. In Bangladesh, the Rural Maintenance Programme, which offers seasonal work to destitute women, used drum beats and loudspeakers throughout the locality to announce that recruitment would be taking place within the next few days. Radio and other media offer other means to ensure dissemination of knowledge.

The principle of self-targeting contributes to the cost-effectiveness of programmes. For instance, public works programmes can be designed to both minimise leakage and costs to the local economy (by setting wages at less than the prevailing wage for 
unskilled labour) and by ensuring that employment is provided during the lean season when it does not compete with demand for agricultural labour. They can be designed with a view to balancing employment generation and infrastructure formation, thereby promoting local development objectives. The Employment Guarantee Scheme in India, put into place by the state of Maharashtra in response to a severe drought in 1970-3 and given statutory status in 1977, is one of the most widely cited examples of a public works programme which sought to promote a rights-based approach through its guarantee of work within a certain radius to those who demand it. Together with the provision of crèches on site and the payment of the same piece rates, regardless of gender, it has also been cited for its track record in attracting female beneficiaries.

The use of public works to build local infrastructure can also generate multiplier effects in both the local economy and in terms of access to social services. Evaluation of CARE's rural maintenance programme in Bangladesh found not only effects in terms of local entrepreneurial activity but also gender-related effects in relation to girls' ability to go to school and women's ability to travel to health clinics (Langworthy 1999).

There is some debate as to the effectiveness of cash versus in-kind transfers. In areas where input markets are missing or imperfect, public works programmes that provide agricultural starter packs have been one way in which they have contributed to productive gains in many parts of Africa. Food transfers may also be preferable where markets and administrative capacity are weak. In other circumstances, there may be strong arguments for cash transfers, both conditional and unconditional. Cash transfers enable choice on the part of the recipient and are less disruptive of local markets. Indeed, there is evidence that the provision of regular and predictable cash transfers, as in social pensions provided to the elderly in countries in Latin America, Africa and Asia, can stimulate the local economy. Anecdotal evidence suggests that in times of crisis, they may protect against abandonment of the elderly (Farrington et al. 2003). Conditional cash transfers are being increasingly adopted as an effective tool for combining social protection objectives with the achievement of certain human development goals.

\subsection{The exercise of voice: promoting participatory} democracy

Group-based identity affects the composition of the political power, access to public institutions and the confidence that different sectors of the population have in the ability of government to rule fairly: 'If the public sector is to function effectively and enjoy widespread legitimacy, all groups in society must feel a sense of belonging, representation and shared interest in the institutions that govern their lives' (Bangura 2003). India has long used reservation policies to promote dalit and adivasi presence in public life through reserved seats in parliament and other elected bodies proportional to their presence in the population, quotas for admission into secondary schools, colleges, medical and engineering schools and employment in government services and enterprises.

The Chinese constitution mandates equality for all ethnic groups and prohibits discrimination against them. The needs of minorities appear to have been served relatively well, with minimal opposition from the majority Han. These include family planning preferences (reprieve from restrictions on number of children), educational preferences, hiring and promotion of minority cadres and leadership and minority representation in representative bodies.

Strengthening the voice of the socially excluded in policy and political processes will mean changing the way that these processes are done. The People's Campaign of Decentralised Planning (India) was launched by the government of Kerala in 1996; it involved the devolution of significant resources and authority to the panchayats (village councils) and municipalities and also mandated village assemblies and citizen committees to plan and budget local development expenditures. Nearly one in four households attended village assemblies in the first two years of the campaign and despite routinisation of the process over time, the assemblies continue to draw large numbers. Large numbers of citizens have undergone training in planning and budgeting and the committees that actually design budgets have been made up of civil society actors.

Most relevant to the theme of this article is the finding that ' $A$ redesign of institutional incentives and new mobilisation efforts saw women account for 40 per cent of the participants in village assemblies, much higher than elsewhere in India, 
while the participation of dalits has exceeded their representation in the population' (World Bank 2006). A large survey of key respondents found that 'disadvantaged groups' were the main beneficiaries of targeted schemes. Similarly, positive accounts also emerge in relation to West Bengal. There is also evidence that over time, women members elected to local councils exercise greater voice on their own account rather than as proxies for powerful men within their families or communities (Chattopadhyay and Duflo 2004; Sen 2000).

Capacity for political participation can also be built by engaging communities in the design and management of community development projects at the local level, but with due regard for building in mechanisms to reach excluded groups. $A$ review of microfinance interventions across the world identifies the kind of design features that are most likely to build social capital and collective capability among socially excluded groups, and thus enhance their capacity to act as citizens (Kabeer 2005c; Dash and Kabeer 2005). The use of social funds to finance community-designed projects has had uneven impacts in terms of addressing poverty and tackling social exclusion. In Pakistan, a recent evaluation suggests that it is primarily private contractors who are submitting proposals for these projects (Rural Development Policy Institute 2005). However, in other places, there is evidence that these funds can be used to promote greater democracy in decision making as well as providing training in citizenship skills. In Indonesia, the Kecamatan Development Project operates in 28,000 villages and seeks to increase political agency of marginalised groups. It allocates grant money at sub-district level for which several groups of villagers (two of whom must be women) compete for funds on the basis of

\section{Notes}

1 About 70 per cent of the world's indigenous and tribal people lie in Asia and the Pacific (Tomei 2005). In India alone, there are 400 tribal groups, numbering around 60 million people.

2 The estimates are taken from Thorat and Lovis (2003); Xaxa (2003); Dubey (2004); de Haan and Dubey (2004) and de Haan (2004). presentation of a formal sub-project proposal. Results include not only basic facilities but also a new style of group redefinition and representation.

Finally, lessons from the use of 'rights-based approaches' in the Asia-Pacific region underline the importance of multi-actor and multi-pronged approaches in addressing the challenge of social exclusion. This is well illustrated by the Right to Food campaign in India (Banerjee et al. 2005). Along with various schemes to promote greater food security for the poor and marginalised, such as the Public

Distribution System and the obligation of states to introduce midday meals in all schools, the government of India has passed the Rural Employment Guarantee Act (2005), which guarantees all the right to work for a certain number of days a year, in response to active campaigning by civil society organisations. The campaign has used public interest litigation to change legislation, and worked with public officials to enlist their participation in public hearings (particularly in states that have witnessed deaths from starvation in recent years) so that they could respond better to claims and were able to develop a regular system for monitoring the provision of midday meals to be used on a nationwide basis. Unterhalter and Dutt (2001) have drawn attention to the complementarity between the government's District Primary Education Program in India, with its capacity for outreach, and the Mahila Samakhya Program, with its emphasis on gender equity. Each complements the strength of the other. Cortillo and Kabeer (2005) found that SHARE, a microfinance organisation in Andhra Pradesh, strengthened the economic capacity of the women in the groups that it organised while their simultaneous membership of government self-helps promoted their political access.

3 Figures are cited in a forthcoming DFID report on Social Exclusion in Nepal.

4 The Interregional Programme to Support SelfReliance of Indigenous and Tribal Peoples through Cooperatives and Self-Help Organisations. 


\section{References}

Amin, S. and Arends-Kuenning, M. (2000) The Effects of Schooling Incentive Programs on Household Resource Allocation in Bangladesh, Working Paper 133, New York: Population Council

Banerjee, U., Naidoo, V. and Gonsalves, C. (2005) 'The Right to Food Campaign in India: A Case Study of Entitlement-Oriented Rights-Based Strategies Used to Reclaim the Right to Food for Vulnerable and Marginalised Groups', in $\cup$. Banerjee (ed.), Lessons Learned From Rightsbased Approaches in the Asia-Pacific Region, Bangkok: UNDP/OHCHR (United Nations Development Programme/Office of the United Nations High Commissioner for Human Rights)

Bangura, Y. (2003) 'Ethnicity, Inequality and the Public Sector: A Comparative Study', background paper for project on Ethnic Structure, Inequality and Governance of the Public Sector, Geneva: United Nations Research Institute for Social Development

Beall, J. (2006) 'Cities, Terrorism and Development', Journal of International Development 18.1: 105-20

Beall, J. (2002) Globalisation and Social Exclusion in Cities: Framing the Debate with Lessons from Africa and Asia, DESTIN Working Paper Series 02-27, London: London School of Economics

Beall, J. (1997) 'Valuing Difference and Working with Diversity', in J. Beall (ed.), A City for All: Valuing Difference and Working with Diversity, London: Zed Press

Betancourt, R. and Gleason, S. (2000) 'The Allocation of Publicly-Provided Goods to Rural Households in India: On Some Consequences of Caste, Religion and Democracy', World Development 28.12: 2,169-82

Bharat, S., Patkar, A. and Thomas, D. (2003) Mainstreaming Equity and Access into the Reproductive and Child Health Programme, London: Department for International Development (DFID) Health Systems Resource Centre

Borooah, V. and lyer, S. (2005) 'Vidya, Veda and Varna: The Influence of Religion and Caste on Education in Rural India', Journal of Development Studies 81.4: 60

BRAC (2004) Towards a Profile of the Ultra Poor in Bangladesh: Findings from CFPR/TUP Baseline Survey, Bangladesh: Bangladesh Rural Advancement Committee

Carraro, L. (2004) A Quantitative Assessment of Social Exclusion in Pakistan, Oxford: Oxford Policy Management
Chattopadhyay, R. and Duflo, E. (2004) 'Impact of Reservations in Panchyati Raj: Evidence from a Nationwide Randomised Experiment', Economic and Political Weekly 39.9: 979-86

Conway, T. and Norton, A. (2002) 'Nets, Ropes, Ladders and Trampolines: The Place of Social Protection within Current Debates on Poverty Reduction', Development Policy Review 20.5: 533-40

Cortillo, M.J. and Kabeer, N. (2005) 'Methodological and Organisational Learnings from Impact Assessment Studies: The Case of SHARE, India', in A. Brody, M. Greeley and K.Wright-Revelledo (eds), Money with a Mission 2: Managing Social Performance, Rugby: Intermediate Technology Development Group

CSR (2004) A Report on Begging in Pakistan, Karachi: Collective for Social Research

Dash, A. and Kabeer, N. (2005) 'The Challenge of Sustainability in India's Poorest State: The Case of CYSD', in A. Brody, M. Greeley and K. WrightRevelledo (eds), Money with a Mission 2: Managing Social Performance, Rugby: Intermediate Technology Development Group

de Haan, A. (2004) 'Disparities within India's Poorest Regions: Why do the Same Institutions Work Differently in Different Places?', background paper for World Development Report 2006: Equity and Development

de Haan, A. and Dubey, A. (2004) 'Conceptualising Social Exclusion in the Context of India's Poorest Regions: A Contribution to the QuantitativeQualitative Debate', paper presented at the Q-squared in Practice: Experiences of Combining Qualitative and Quantitative Methods in Poverty Appraisal Conference, 15-16 May, Toronto

Demery, L. and Walton, M. (2000) 'Are Poverty and Social Goals for the 21st Century Attainable?' in R. Halvorson-Quevedo and R. Schneider (eds), Waging the Global War on Poverty, Paris: OECD (Organisation for Economic Cooperation and Development)

Devereux, S. and Sabates-Wheeler, R. (2004) Transformative Social Protection, IDS Working Paper 232, Brighton: IDS

Dreze, J. and Kingdon, G. (2001) 'School Participation in Rural India', Review of Development Economics 5.1: 1-33

Dubey, A. (2004) 'Quantitative Analysis of Social Group Disparities with Evidence for DFID Partner States', background paper, Department for International Development, Delhi 
Duong, D.V., Binns, C.W. and Lee, A. (2004) 'Utilization of Delivery Services at the Primary Health Care Level in Rural Vietnam', Social Science and Medicine 59: 2,585-95

Easterly, W. (2001) 'The Political Economy of Growth Without Development: A Case Study of Pakistan', paper for the Analytical Narratives of Growth Project, Kennedy School of Government, Harvard University

EDA Rural Systems Pvt Ltd (2004) Impact Monitoring and Assessment Report 2 - Baseline - The Maturing of Indian Microfinance: A Longitudinal Study, Delhi: SIDBI Foundation for Micro-Credit (SFMC)

Estivill, J. (2003) Concepts and Strategies for Combating Social Exclusion: An Overview, Geneva: International Labour Office

Farrington, J. (2005) Recognising and Tackling Risk and Vulnerability Constraints to Pro-Poor Agriculture, London: Department for International Development Renewable Natural Resource and Agriculture Team

Farrington, J., Saxena, N.C., Barton, T. and Nayak, R. (2003) Post Offices, Pensions and Computers: New Opportunities for Combining Growth and Social Protection in Weakly Integrated Areas?, Natural Resources Perspectives Paper 87, London: Overseas Development Institute

Foggin, P., Armijo-Hussein, N., Marigaux, C., Zhu, H. and Liu, Z. (2001) 'Risk Factors and Child Mortality Among the Miao in Yunnan, Southwest China', Social Science and Medicine 53: 1,683-96

Gangopadhyay, S. and Wadhwa, W. (2003) Are Indian Female Headed Households More Vulnerable to Poverty? Delhi: India Development Foundation

Gardener, J. and Subrahmanian, R. (2005) Tackling Social Exclusion in Health and Education in South Asia, Delhi: Department for International Development

Government of Pakistan (2003) Participatory Poverty Assessment: Synthesis Report, Islamabad: Planning Commission

Gustafsson, B. and Shi, L. (2003) 'The Ethnic Minority-Majority Income Gap in Rural China During Transition', Economic Development and Cultural Change 51.4

Hoff, K. and Pandey, P. (2004) Belief Systems and Durable Inequalities: An Experimental Investigation of Indian Caste, Policy Research Working Paper Series 3351, Washington DC: World Bank

IFPRI (2005) Food for Education: Feeding Minds Reduces Poverty, International Food Policy Research Institute, www.ifpri.org/pubs/ib/ib4/ ib4 results.asp
Kabeer, N. (2005a) 'Social Exclusion: Concepts, Findings and Implications for the MDGs', paper prepared for DFID Strategy Paper on Social Exclusion, London: Department for International Development

Kabeer, N. (2005b) 'Direct Impacts of Microfinance: Social Exclusion and Citizenship' in J. Copestake, M. Greeley, S. Johnson, N. Kabeer and A. Simanowitz (eds), Money with a Mission 2: Microfinance and Poverty Reduction, Rugby: Intermediate Technology Development Group

Kabeer, N. (2005c) 'Wider Social Impacts of Microfinance for the Millennium Development Goals' in J. Copestake, M. Greeley and K. WrightRevelledo (eds), Money with a Mission 2: Microfinance and Poverty Reduction, Rugby: Intermediate Technology Development Group

Kabeer, N. (2004) Snakes, Ladders and Traps: Changing Lives and Livelihoods in Rural Bangladesh, 1994-2001 CPRC Working Paper 50, www.chronicpoverty.org

Kabeer, N. (2000) 'Social Exclusion, Poverty and Discrimination: Towards an Analytical Framework' IDS Bulletin 31.4: 83-97

Kabeer, N. and Van Anh, T.T. (2001) Leaving the Ricefield but not the Village: Gender, Livelihoods Diversification and Implications for Pro-Poor Growth in Rural Vietnam, Discussion Paper 13, Geneva: UNRISD (United Nations Research Institute for Social Development)

Kozel, V. and Parker, B. (2003) 'A Profile and Diagnostic of Poverty in Uttar Pradesh', Economic and Political Weekly 38.4: 385-403

Langworthy, M. (1999) Final Impact Assessment Report of IFFD Project, Dhaka: CARE-Bangladesh

Lanjouw, P. and Zaidi, S. (2002) 'Andhra Pradesh Poverty Note: A Preliminary Profile and Emerging Issues' (unpublished), World Bank

Larsen, P. (2003) Indigenous and Tribal Children: Assessing Child Labour and Education Challenges, Child Labour and Education Working Paper, Geneva: ILO (International Labour Organization)

Lucas, H. (2004) Exclusion and the MDGs: Evidence on the Links, background paper, Department for International Development

Nambissan, G. (2000) 'Identity, Exclusion and the Education of Tribal Communities', in R. Wazir (ed.), The Gender Gap in Basic Education: NGOs as Change Agents, New Delhi: Sage Publications

Nambissan, G. (1996) 'Equity in Education? Schooling of Dalit Children in India', Economic and Political Weekly 31.16 and 17: 1011-24 
Rural Development Policy Institute (2005) Baseline Survey of Hafizabad District. Social, Economic and Political Conditions for Good Governance, Islamabad: report to Japan International Cooperation Agency (JICA)

Sen, S. (2000) Towards a Feminist Politics? The Indian Women's Movement in Historical Perspective, Policy Research Report on Gender and Development, Working Paper Series 9, Washington DC: World Bank

Sender, J. (2003) 'Rural Poverty and Gender: Analytical Frameworks and Policy Proposals', in Ha-Joon Chang (ed.), Rethinking Development Economics, London: Anthem Press

Sender, J. and Pincus, J. (2001) Preliminary Results from the Indonesian People's Security Survey: Characteristics of the Most Insecure and Vulnerable Households, Geneva: ILO (International Labour Organization)

Stewart, F. (2002) Horizontal Inequalities: A Neglected Dimension of Development, Working Paper Series 1, Oxford: Centre for Research on Inequality, Human Security and Ethnicity (CRISE), Queen Elizabeth House, University of Oxford

Swinkels, R. and Turk, C. (2004) 'Poverty and Remote Areas: Evidence from New Data and Questions for the Future', background paper for the PAC Conference, 24-26 November
Thorat, S. and Louis, P. (2003) 'Exclusion and Poverty in India: Scheduled Castes, Tribals and Muslims', overview paper, India: Department for International Development

Tomei, M. (2005) Indigenous and Tribal Peoples: An Ethnic Audit of Selected Poverty Reduction Strategy Papers, Geneva: ILO (International Labour Organization)

Unterhalter, E. and Dutt, S. (2001) 'Gender, Education and Women's Power: Indian State and Civil Society Intersections in DPEP (District Primary Education Programme) and Mahila Samakhya', Compare 31.1: 57-73

Vandergeest, P. (2001) 'Racialization and Citizenship in Thai Forest Politics', Society and Natural Resources 16: 19-37

Varshney, A. (2001) 'Ethnic Conflict and Civil Society: India and Beyond', World Politics 53.3: 362-98

Vietnam Consultative Group (2003) Poverty: Vietnam Development Report 2004, joint donor report, 2-3 December 2003, Hanoi

World Bank (2006) World Development Report 2006: Equity and Development, Washington DC: World Bank and Oxford University Press

World Bank (2000/2001) World Development Report 2000-2001: Attacking Poverty, Oxford: Oxford University Press

Xaxa, V. (2003) 'Adivasis in India', background paper, India: Department for International Development 